\title{
The Global Need for Plant Breeding Capacity: What Roles for the Public and Private Sectors?
}

\author{
Michael Morris \\ Environmentally Sustainable Social Development Division, World Bank, Washington, DC 20433 \\ Greg Edmeades \\ Maizways, 43 Hemans Street, Cambridge, New Zealand \\ Eija Pehu \\ Agriculture and Rural Development, World Bank, Washington, DC 20433
}

\begin{abstract}
For several decades after plant breeding emerged as a recognized field of science in the late 19th century, almost all plant breeding activities took place in public institutes, and almost all plant breeders received their scientific education in public universities. Over time, the locus of plant breeding gradually shifted to the private sector, driven by the commercialization of agriculture and the associated privatization of agricultural research. The training of plant breeders, however, remained largely a public undertaking. Then, as now, private firms had few incentives to invest in an activity whose benefits accrue over a long period and are difficult to appropriate, since plant breeding skills are not firm-specific and breeders can easily offer their services to rival employers.
\end{abstract}

For more than 100 years, the arrangement worked well even as it continued to evolve. The training of plant breeders, recognized as being a public good, was paid for mainly by governments, and plant breeding research, considered increasingly to be a private good, was funded more and more by private firms, mainly seed companies. Today, however, the arrangement is threatening to unravel. The numbers of students entering universities to be trained as plant breeders appear to be falling, as do the numbers of university graduates available to the plant breeding profession. Challenged to attract qualified staff, universities and seed companies in industrialized countries have been filling positions by hiring experienced breeders away from positions in developing countries. In recent years, even this strategy has not been enough: the number of new entrants into the plant breeding industry has continued to decline, and the plant breeding profession has grayed noticeably, especially in the public sector. Many fear that if current trends are not reversed, the plant breeding industry will soon face a critical shortage of skilled breeders.

This paper examines factors that have contributed to the decline in capacity building within the agricultural sciences and considers changes that will be needed to prevent what some feel could develop into a crisis for the international plant breeding industry. In addition to this introduction, the paper includes four sections. Section 2 discusses the knowledge and skills needed by plant breeders. Section 3 discusses how that knowledge and those skills have been acquired in the past and how they are being acquired today. Section 4 summarizes trends affecting global agriculture and shows how these have contributed to declining invest- ment in the education of agricultural scientists. Section 5 identifies actions that will be required to rebuild capacity in international plant breeding and contemplates needed changes in the roles of key actors.

\section{PLANT BREEDERS AND PLANT BREEDING}

What do plant breeders do? Observed plant performance or phenotype $(\mathrm{P})$ can be described algebraically as $\mathrm{P}=\mathrm{G}+\mathrm{E}+(\mathrm{G} \times \mathrm{E})+e$, where $\mathrm{G}=$ effects arising from the plant's genetic constitution or genotype, $\mathrm{E}=$ effects attributable to the environment, $\mathrm{G} \times \mathrm{E}=$ effects that reflect the interaction of $\mathrm{G}$ with $\mathrm{E}$, and $e=$ effects due to random error. Plant breeders are concerned with dissecting P into its various components. The purpose of the dissection is to be able to manipulate $\mathrm{G}$ effectively and efficiently, so that genetic gain can be maximized. Plant breeding is both an art and a science, where the art encompasses careful observations of plant behavior in the field and to some extent the choice of parents for crosses, and the science relates to knowledge of genetics, physiology, pathology, entomology, statistics, and other disciplines (Lamkey, 2003).

Skills needed by plant breeders. The central skill in plant breeding has always been knowledge of genetics, the study of the particulate nature of inheritance, where the units of inheritance are individual genes. Modern quantitative genetics as learned by today's students is based on statistical models, but the underlying theory continues to be grounded in the elementary laws of inheritance formulated by Mendel nearly 150 years ago. Simple traits such as flowering date typically have a high heritability (i.e., a large proportion of the observed variation for these traits is also observed in the next generation) and are regulated by few genes with large effects. Complex quantitative traits such as yield have a relatively low heritability (i.e., they are controlled by many genes that interact with each other and with the environment, sometimes unpredictably). Plant breeders use their knowledge of quantitative genetics, with its foundation in statistics, mathematics, and Mendel's laws, to estimate heritability, genetic variation, gene action, and $\mathrm{G} \times \mathrm{E}$ interaction-all critical to the design of an efficient breeding and testing system. Most successful breeders also have a good functional knowledge of physiology, pathology, entomology, soil science, and experimental design. Until the late 1980s, the plant breeder's tool kit consisted mainly of what could be characterized as a quantitative genetics-based knowledge, and the education and training of plant breeders revolved around developing this knowledge.

New laboratory-based tools. The discovery during the 1950s and 1960s of the structure and roles of DNA and RNA led to the development of molecular genetics and gave rise to a wealth of new genetic information. By the late $1980 \mathrm{~s}$, this information had been used to develop powerful new breeding tools. Inheritance could now be linked to the presence of specific nucleotide sequences in successive generations. Variations in these sequences at different physical locations (loci) in the genome of an individual generally give rise to different genes, while variations at a single locus give rise to different forms of the same gene, or alleles. For the first time, breeders were able to relate variation in phenotype to variation at the DNA sequence level. This meant they could contemplate breeding at the sequence level, rather than at the level of the whole plant genotype seen through the somewhat murky lens provided by the plant phenotype.

To use and exploit DNA-based information for crop improvement, breeders must acquire knowledge and skills that relate to the identification and manipulation of specific DNA sequences. Three major areas of activity can be distinguished whose successful use requires command of extensive technical knowledge and proficiency in complex laboratory techniques.

Genomics deals with the physical structure of the genome (structural genomics), as well as with gene products and gene interactions (functional genomics), and is built on a foundation of molecular genetics, automated laboratory tools, and bioinformatics.

Transformation, the process through which genes can be moved across species boundaries, requires identifying and isolating the desired gene, transferring the gene into the genome of the target plant, usually using a bacterium as a vector, and then regenerating entire fertile plants from the transformed tissue. It forms the basis of the burgeoning adoption of genetically modified crops.

Marker-assisted selection (MAS) involves the transfer of a piece of DNA (including the gene of interest) associated with a specific phenotype, with molecular markers being used to identify the DNA fragment in successive 
generations. Molecular markers are generally small segments of DNA that recognize discrete parts of the genome through sequence complementation.

Application of modern plant breeding methods based on genomics, transformation, and marker-assisted selection requires highly specialized knowledge and skills. Does this mean that today's plant breeders need to be experts in both conventional breeding and molecular breeding techniques? Probably not - the range of knowledge is simply too great for most individuals to master. For the majority of commercial breeders, a solid grounding in the more traditional plant breeding skills continues to be the most useful skill set, but they must be familiar with the new techniques, understand their potential, and be able to collaborate with others having the appropriate expertise (Tinker 2002).

Newfield-based tools. Because the value of a plant variety is determined by its performance in farmers'fields, commercial seed companies sell products based on phenotypes, not genotypes. Gene researchers and transgene developers can conduct much of their research in controlled laboratory environments, but breeders charged with developing final products normally must work in the field, preferably within the target environment where the cultivar is expected to perform. Field-based research generates information about germplasm that cannot be obtained in any other way. As part of the art of breeding, breeders need to see first hand the interaction between $\mathrm{G}$ and $\mathrm{E}$, as well as the response of the phenotype to interactions among genes. These effects must be measured as precisely as possible, since the value of any genetic modification is assessed through some measurable phenotypic change.

Recently, the capacity to conduct highthroughput precise assessments of plant phenotypes in the field has fallen behind breeders' ability to characterize genotypes with complex laboratory techniques (Edmeades et al., 2004; Sinclair et al., 2004). The imbalance reflects changing patterns in research funding, a move among scientists away from the field and towards the laboratory, and attrition among skilled field researchers. The cost of field phenotyping has remained static while the cost of generating sequence-level information has fallen dramatically, thus tipping the balance in favor of laboratory activities. This is a problem for the industry, because genotypic information is only as useful as the quality of the phenotypic information with which it is associated.

One result has been increased pressure on field based researchers to reduce costs through improvements in the design, management, and analysis of experiments (Gilmour et al., 1998). By mechanizing basic plot operations such as sowing, fertilizer application, weed control, and harvesting, it is possible to increase the numbers of progenies that can be evaluated. By improving the precision of measurements, especially with high-throughput measurement techniques that involve remote sensing, rates of genetic gain can be accelerated. The modern breeder thus must also be familiar with the operation of plot equipment and measurement instruments, as well as with the computer software that manages logistics and data analysis.

What is a plant breeder today? Lee and Dudley (2005) describe a plant breeder as a systems biologist who understands the components of $\mathrm{G}, \mathrm{E}$, and $\mathrm{G} \times \mathrm{E}$; locates new sources of genetic variation that correct weaknesses in cultivars and introgresses them efficiently; and integrates the relevant disciplines in a field setting to create a new product that is superior for target traits, stable in performance across locations, and acceptable to growers and consumers. A plant breeder possesses strong knowledge of genetics and information management and draws upon elements of many other disciplines, including pathology, entomology, crop physiology, experimental design and analysis, remote sensing, and soil and environmental sciences. Although a plant breeder must be comfortable with laboratory techniques, she or he is committed first and foremost to high quality, high throughput field work, observing plant response in the target environment. It is in the field that putative yield enhancing mechanisms are properly tested and where they must demonstrate improved or stabilized crop yields under realistic production conditions. Abreedermust be able to understand, critically evaluate, and use new methods emerging from many diverse fields of investigation and different disciplines, and to evaluate their potential for improved rates of genetic gain. This calls for flexibility, openness, a commitment to staying abreast of the professional literature, and a willingness to retrain.

In addition to having technical breeding expertise, today's plant breeder must also possess legal knowledge, business acumen, and people skills. The uses of many new technologies and sources of genetic variation are now constrained by intellectual property laws and/or biosafety regulations, including those relating to food safety. The cost of regulatory approval for a single transgenic event in developing countries can be as much as $\$ 4$ million (Cohen, 2005). This calls for a new level of field and financial management and a detailed appreciation of bioregulatory law, since oversights can be expensive and sometimes fatal to small private sector companies (Louwaars et al., 2005). With more and more breeding programs guided by profit considerations, today's plant breeder also must have a good understanding of the factors that affect the adoption of new varieties, patterns of adoption, and reasons for their eventual success or failure. Last but not least, today's plant breeder must be able to work effectively as a member of a team. Teams are increasingly important in research, where the breadth of expertise required for success is well beyond the scope of any individual member. This important aspect is not a traditional part of graduate training, but it is essential for success in research, especially in the private sector (Edmeades et al., 2004).

\section{EDUCATION AND TRAINING OF PLANT BREEDERS}

How do plant breeders obtain the knowledge and skills needed to be successful? With plant breeding as with other fields, when thinking about capacity building it is useful to distinguish between education and training (Lee and Dudley, 2005). Education is strategic in nature and enables the student to understand the principles and theory that underlie the activities in which breeders engage. Education creates a conceptual framework, a big picture for the discipline, that allows practitioners to analyze situations and make intelligent choices and good judgments when confronted by changing circumstances - a new crop, a new disease, lack of genetic variation, new methodology, etc. Training, on the other hand is more tactical in nature; it typically involves drilling in specific techniques that focus on a particular problem. As Lee and Dudley (2005) note, it is important that students be educated to become plant breeders, not maize breeders or wheat breeders or rice breeders. Training instills knowledge that may be quite cropspecific, whereas education instills knowledge that is more likely to be applicable across all crops. Thus education subsumes training, and not vice versa.

Education in breeding principles is particularly important for students from developing countries who study in the U.S., since any crop-specific training they receive as part of their degree programs will likely pertain to maize, soybean, cotton, wheat, tomato, alfalfa, sorghum or potato, the eight crops that consume $55 \%$ of all breeding resources in the U.S. (Frey, 1996). For many, the knowledge and skills they acquire through crop-specific training turns out to have limited use when they return home. This is not to say that training is unimportant, however. The most effective training ground for students is a university department with an active plant breeding program that is closely aligned to needs of seed companies or farmers. Hands-on training in a breeding program with accountability to clients is an indispensable confidence builder, and the global decline in the strength and product orientation of university breeding programs has seriously weakened this important aspect of capacity building.

Industrialized countries. The U.S. land grant universities historically have played a leading role in training plant breeders from all over the world. Their agricultural mandate, along with their abundant endowments of land, led naturally to the development of large public breeding programs focused mainly on crops of economic importance in the U.S. The presence of USDA-ARS research programs has added synergistically to the depth and scope of research and supervision possible in many universities (Lamkey, 2003). Yet many university breeding programs are today in decline, pressured at the upper end of the research pipeline by increased competition for funds with the new fields of genomics, molecular breeding, and bioinformatics, and pressured at the lower end by an active private sector that has assumed greater responsibility for downstream product development.

Developing countries. Universities offering quality breeding education and training can be found in a handful of developing countries, including India, China, South Africa, Brazil, 
Argentina, Mexico, and Chile. Plant breeders educated today in these elite universities are generally well-versed in conventional breeding principles, although they often lack knowledge of private-sector plot mechanization techniques, and few have been exposed to an extensive multilocation testing system. Most also have a reasonably good theoretical grounding in molecular breeding principles, although rarely can they claim hands-on experience with modern molecular techniques at the level and scale needed to make significant impact. In short, their education is reasonably complete, but their training has many shortcomings. With some relatively modest changes to their curricula, the best of these universities could become centers of excellence in plant breeding for the future.

Elsewhere, the picture is bleaker. Most universities in developing countries unfortunately offer mediocre plant breeding education and substandard training. The reasons are legion and include low staff salaries, persistent teaching overload, inadequate and unstable budgets, poor laboratory facilities and field research stations, lack of access of scientific literature, absence of opportunities to upgrade skills, etc. Because of these and other shortcomings, good staff and bright students have little incentive to remain within the university system. Staff are easily lured away by the private sector, and the good students leave for other universities or transfer into other departments.

Role of the Consultative Group on International Agricultural Research (CGIAR). One reason why capacity building is so weak in many developing countries is that scarce educational resources tend to be dispersed. Rarely are significant numbers of cutting-edge plant breeding researchers concentrated within a single organization or even within a single country. If the existing talent could be aggregated on a regional basis, it might be possible to assemble a critical mass of breeders who could collectively participate in the training of the next generation.

Many believe that the CGIAR centers should fulfill this role. Without question, the plant breeding activities of the CGIAR centers over the past 40 years have had a significant impact on crop production in the developing world (Evenson and Gollin, 2004). The impacts of CGIAR breeding programs are more modest today, as newly released varieties must now compete against varieties released during the 1970 s and 1980 s, rather than against landraces. Most CGIAR centers with breeding programs have access to molecular breeding techniques and bioinformatics, although individual centers generally do not have a criti-

Fig. 1. Real public and private expenditures on plant breeding in the U.S. (Heisey et al., 2002). cal mass of staff or facilities to be innovation leaders in biotechnology. Their role as breeding centers has also evolved towards prebreeding, as other suppliers such as the private sector and strong national public breeding programs have increased their activities, especially with commercially important crops such as maize and rice.

What is the role of the CGIAR centers in educating and training plant breeders? Since they are not degree-granting institutions, the role of the CGIAR centers in educating breeders has necessarily been limited; most often it has taken the form of supervision of thesis research. The CGIAR centers have however played an important role in training plant breeders, mainly by offering practical, field-based training courses from 3 to 6 weeks in duration that attract the participation of scientists and technicians from national public breeding programs. By 1992, the CGIAR centers had trained more than 45,000 technical staff, many of them in plant breeding methods (CGIAR, 2005).

\section{TRENDS AFFECTING INTERNATIONAL PLANT BREEDING}

Previous sections of this paper have described the skills needed by modern plant breeders and discussed how these skills have traditionally been acquired. We now turn to a discussion of factors that affect agricultural capacity building in general and plant breeding capacity building in particular.

\section{Trends in global agriculture}

Several major trends are transforming global agriculture and in the process altering the environment in which agricultural research organizations operate. These changes have affected the way plant breeding research gets funded and carried out, and they are having profound effects on capacity building efforts in the plant breeding industry.

Commercialization of agriculture. In most industrialized countries, as agriculture becomes more and more commercialized, private firms increase their investment in research, and the arguments in favor of using public funds to support agricultural research become increasingly difficult to sustain. The locus of agricultural research gradually shifts from the public to the private sector, as has happened in the U.S. during the past 40 years (Fig. 1). In many developing countries, where agriculture tends to be more subsistence-oriented and thus less attractive to the private sector, the arguments in favor of public investment in agricultural research are much stronger. That is beginning to change, however. During the past few decades, governments in many developing countries have introduced policy reforms designed to better integrate what were once highly protected domestic agricultural sectors into the global economy. As these reforms give rise to more competitive and commercially oriented agricultural sectors, one would expect to see research migrate from the public sector to the private sector, just as it has done in the industrialized countries. At the same time, reduced public funding of agricultural research will force national research institutes to become more self-supporting, shifting their priority to crops in which benefits from breeding can be appropriated through seed sales or variety royalties.

Strengthening of intellectual property rights regimes. The commercialization of agriculture in many developing countries has been taking place against the backdrop of strengthening intellectual property (IP) rights that among other things have had significant implications for the plant breeding industry (for a recent review, see Louwaars et al., 2005). As a prerequisite to joining the World Trade Organization (WTO), most industrialized and many developing countries have accepted the provisions of the Trade Related Intellectual Property Rights Agreement (TRIPS). This obliges member countries to provide utility patent protection for all types of plant material, except for plant varieties, which must be protected either by patents or by some form of sui generis system

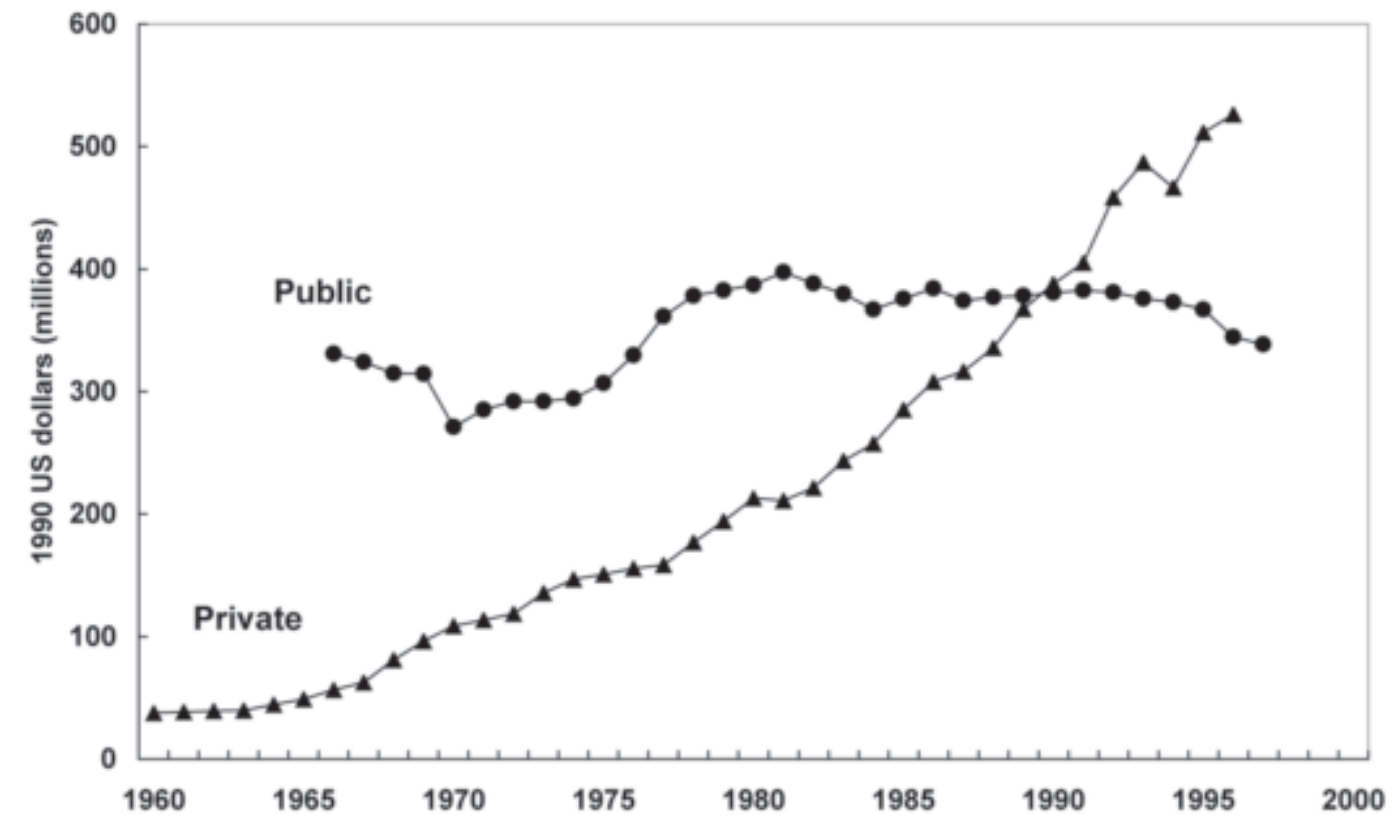




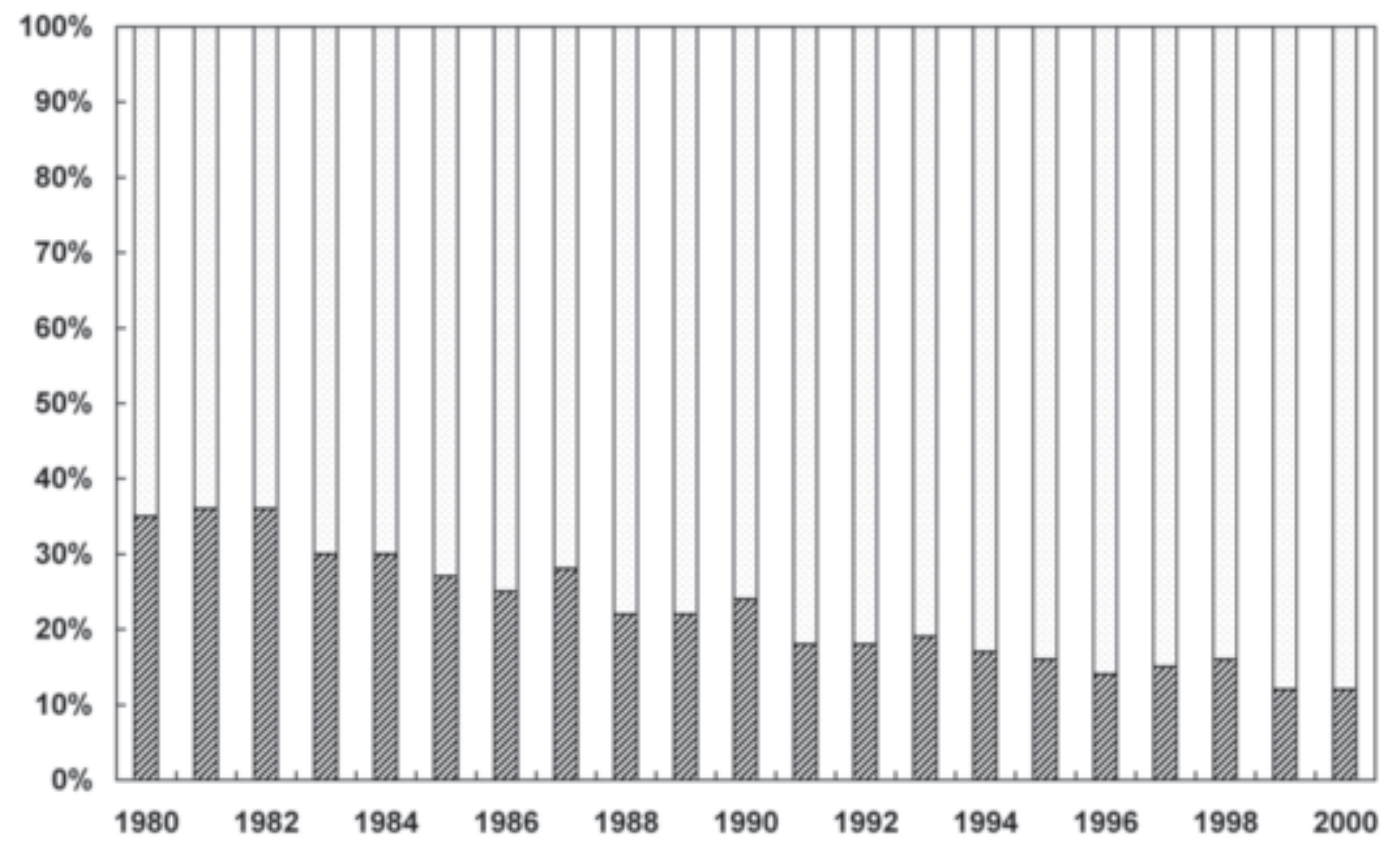

Fig. 2. Share of agricultural lending in Official Developmental Assistance, 1980-2000 (Kane and Eicher, 2004).

(ODA) flows to agriculture have declined in recent years. Across all developing countries, the share of agricultural assistance within total ODA declined from over $35 \%$ in 1981 to $<12 \%$ in 2000 (Fig. 2). A similar decline has been evident in the lending of the World Bank; the share of lending to agriculture has fluctuated over the years, but the overall trend has been downward (Fig. $3)$. The pattern of assistance has varied considerably between regions, however, with agriculture having received a relatively large share of ODA in Asia and a relatively small share in Latin America (Table 1). Regional differences are to

based on plant variety protection (PVP) or plant breeders' rights (PBRs) (Louwaars et al., 2005; Van Wijk, 1997). In recent years, many TRIPS signatories have introduced PVP and/or PBR laws. These measures have strengthened incentives for private firms to invest in plant breeding research, although perhaps less than envisioned when the TRIPS agreement was originally formulated.

Privatization of the plant breeding industry. The increasing commercialization of agriculture, in combination with the strengthening climate for IP rights over plant genetic resources, has given added impetus to the emergence of an international plant breeding industry that is increasingly privatized. Although public breeding programs continue to operate in most countries, public organizations have generally withdrawn from many seed production and distribution activities. Meanwhile, the relaxation of restrictions on entry into the seed industry

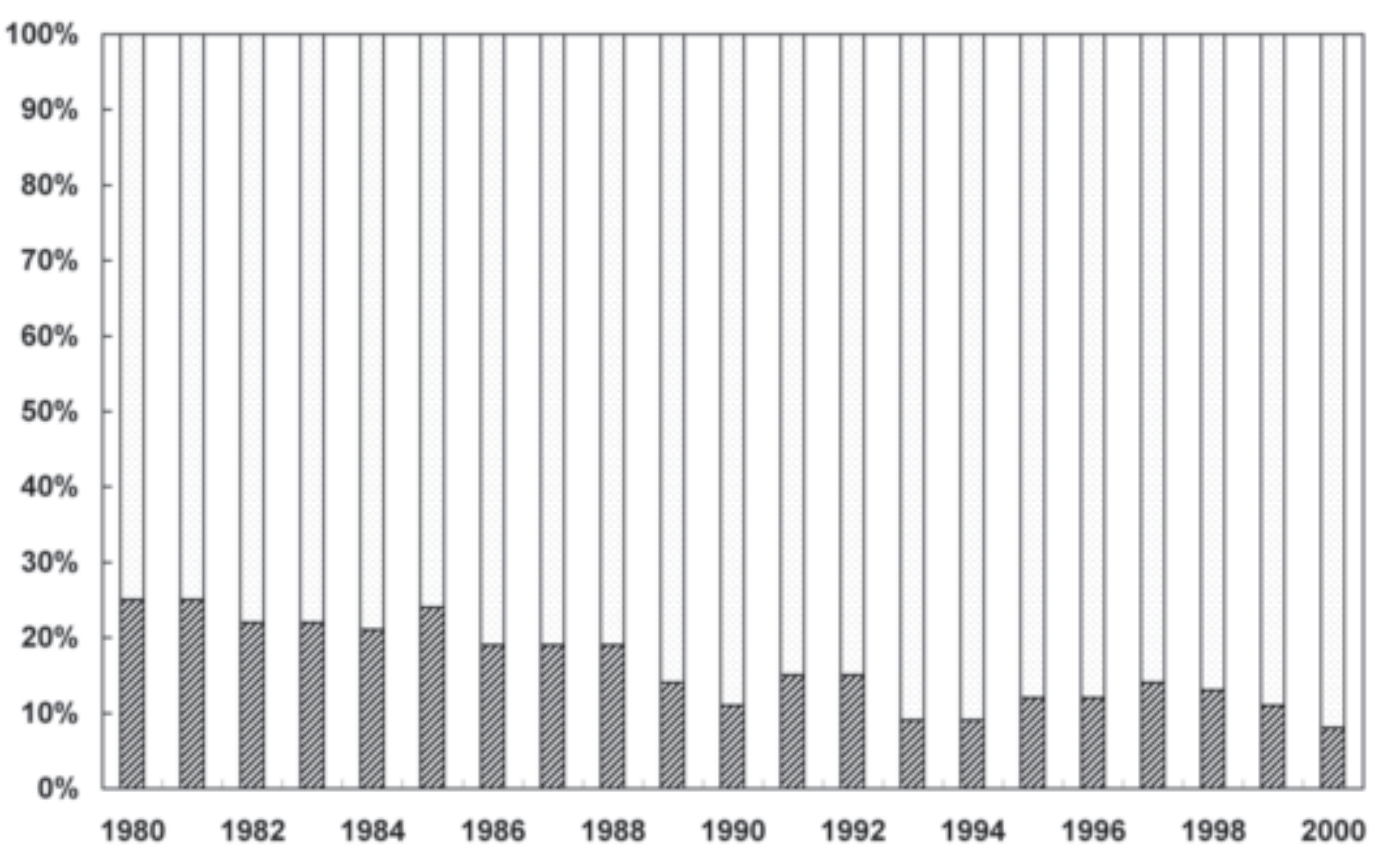

and the lifting of controls on international germplasm flows have opened the door to increased private sector participation (Morris, 1998, 2000). As a result, many countries have seen rapid growth in the number of private seed companies, greater investment in plant breeding research, and greater availability of improved cultivars (Morris and Ekasingh, 2002). Often as national seed industries have matured, significant consolidation has taken place. Smaller companies are being taken over or forced out by larger competitors who are able to exercise greater marketing power and back it up with a steady stream of innovative products that reflects their capacity to conduct product-oriented research.

Decline in official development assistance for agriculture. Somewhat paradoxically, even though agriculture serves as the main engine of economic growth in many developing countries, official development assistance be expected, since the importance of agriculture varies between regions, but the regional differences cannot be explained in those terms. For example in sub-Saharan Africa, where ODA flows have been analyzed in detail by Kane and Eicher (2004), agriculture accounts for a much larger share of the economy, but agriculture receives the same proportion of ODA as in other regions. Regardless of the cause of the decline, the effect has been a sharp decrease in ODA funds available to support public investment in agricultural research and scientific capacity building.

\section{Trends in agricultural research investment}

These trends affecting global agriculture have influenced investment in agricultural research generally and plant breeding research in particular. Training and capacity building in the agricultural sciences have also been adversely affected.

Declining public investment in agricultural research. Globally, public investment in agricultural research reached \$21 billion in the mid-1990s, just under half of which occurred in the industrialized countries (Table 2). In developing countries, public investment in agricultural research rose by $4.5 \%$ annually from 1971 to 1991, more than double the rate in industrialized countries (Table 3 ). The rapid growth has not been sustained, however. During the most recent decade for which data are available, growth in public funding for agricultural research slowed

Fig. 3. Share of World Bank (unpublished data) lending to agriculture, 1980-2000. 
Table 1. Importance of agriculture in official development assistance (ODA), 1971-2001. Adapted from Kane and Eicher (2004).

\begin{tabular}{lrrrr}
\hline & 1971 & 1981 & 1991 & \multicolumn{1}{c}{2001} \\
\hline Total ODA (2001 million dollars) & 26015 & 36195 & 46252 & 54085 \\
ODA to agriculture (percent of total) & 16 & 22 & 13 & 6 \\
Agriculture value added (percent of GDP) & 23 & 19 & 16 & 12 \\
ODA per capita (2001 dollars) $^{\mathrm{z}}$ & 6.8 & 13.4 & 16.5 & 11.7 \\
\hline
\end{tabular}

${ }^{2}$ Low and middle income countries.

Table 2. Global public agricultural research expenditures, 1976-95 (million dollars). The number of countries is in parentheses. Source: Pardey and Beintema (2001).

\begin{tabular}{lrrr}
\hline & \multicolumn{3}{c}{ Expenditures $^{\mathrm{z}}$} \\
\cline { 2 - 4 } & 1976 & 1985 & 1995 \\
\hline Developing countries (119) & 4738 & 7676 & 11469 \\
Sub-Saharan Africa (44) & 993 & 1181 & 1270 \\
China (1) & 709 & 1,396 & 2063 \\
Asia and Pacific, excluding China (23) & 1321 & 2453 & 4619 \\
Latin America and the Caribbean (35) & 1087 & 1583 & 1947 \\
West Asia and North Africa (15) & 582 & 981 & 1521 \\
Industrialized countries (34) & 7099 & 8748 & 10215 \\
Total (153) & 11837 & 16424 & 21692 \\
\hline
\end{tabular}

${ }^{2}$ Units are in 1993 international dollars, using PPP (millions).

Table 3. Trends in global public agricultural research expenditures, 1976-95. Number of countries is in parentheses. Source: Pardey and Beintema (2001).

\begin{tabular}{lccccc}
\hline & \multicolumn{5}{c}{ Annual increases (percent per year) } \\
\cline { 2 - 6 } & $1976-81$ & $1981-86$ & $1986-91$ & $1991-96$ & $1976-96$ \\
\hline Developing countries (119) & 7.0 & 3.9 & 3.9 & 3.6 & 4.5 \\
Sub-Saharan Africa (44) & 1.7 & 1.4 & 0.5 & -0.2 & 1.5 \\
China (1) & 7.8 & 8.9 & 2.8 & 5.5 & 5.2 \\
Asia and Pacific, excluding China (23) & 8.2 & 5.1 & 7.5 & 4.4 & 6.5 \\
Latin America and the Caribbean (35) & 9.5 & 0.5 & 0.4 & 3.5 & 2.5 \\
West Asia and North Africa (15) & 7.4 & 4.0 & 4.2 & 3.5 & 4.8 \\
Industrialized countries (34) & 2.5 & 1.9 & 2.2 & 0.2 & 1.9 \\
Total (153) & 4.5 & 2.9 & 3.0 & 2.0 & 3.2 \\
\hline
\end{tabular}

noticeably, falling from $4.6 \%$ in $1976-81$ to $1.7 \%$ in $1991-96$ across all developing regions. In industrialized countries, growth in public investment in agricultural research has been maintained at the global level, but only because of continued steady growth in the U.S. (Pardey et al., 1999). When the global data are disaggregated, it becomes clear that many smaller industrialized countries have sharply restructured their public sectors, resulting in steep declines in public funding for agricultural research during the most recent decade. At the international level, funding for CGIAR centers showed similar trends. Resources flowing into the CGIAR system grew rapidly throughout the 1970s and more slowly during the $1980 \mathrm{~s}$ before declining in real terms during the 1990s (Fig. 4).

Many factors have contributed to the observed decline in public support to agricultural research. While these have varied from country to country, recurring themes include fiscal austerity programs linked to structural adjustment reforms, growing competition for public funds, a lack of appreciation among policy makers of the

Fig. 4. Real expenditures of the Consultive Group on International Agricultural Research, 19602000 (unpublished data). public-good nature of much agricultural research, the weak political constituency for research from farmers and agribusiness, and long-term declines in global commodity prices (Byerlee et al., 2002). Another contributing factor may have been the proliferation of nongovernmental organizations (NGOs) engaged in agricultural development work. While many NGOs have proven to be effective in transferring improved technology to farmers, they are rarely involved in research per se.

In many developing countries, the flat or slightly downward trend in public investment in agricultural research has led to a disproportionately large reduction in research capacity. While research expenditures have stagnated, the number of scientists employed in public research institutes has continued to increase, resulting in declining expenditure per scientist, a rise in the share of expenditures allocated to salaries, and reductions in operational budgets (Eicher, 1990). Faced with increasing budgetary pressure, national agricultural research organizations in many developing countries have recently started to downsize, restructure, and consolidate.

Rising private investment in agricultural research. Declining public investment in agricultural research has been offset by an increase in private investment. The trend has been most noticeable in many industrialized countries, although it has also occurred in some developing countries.

Private investment in plant breeding research began to accelerate during the 1930s following the development of hybridization technologies. Early breeding work financed by private companies focused mainly on vegetables, flowers, and a handful of commercially important field crops such as maize, soybean, cotton, and oilseeds. After rising steadily for many years, the level of private investment in plant breeding research began to shoot up exponentially during the 1990s as a small number of agribusiness giants formed through mergers of seed and chemical companies began to direct significant sums of money into biotechnology. Total investment by private firms in agricultural research is now estimated to exceed $\$ 35$ billion, most of it concentrated in North America and Europe (Table 4).

Detailed evidence on private agricultural research in developing countries is fragmentary. Pray and Fuglie (2002) conducted a survey of seven Asian countries during the mid-1990s. These seven countries showed a clear pattern of overall growth, but there were considerable differences in the composition of research investments (Table 5). Outside of

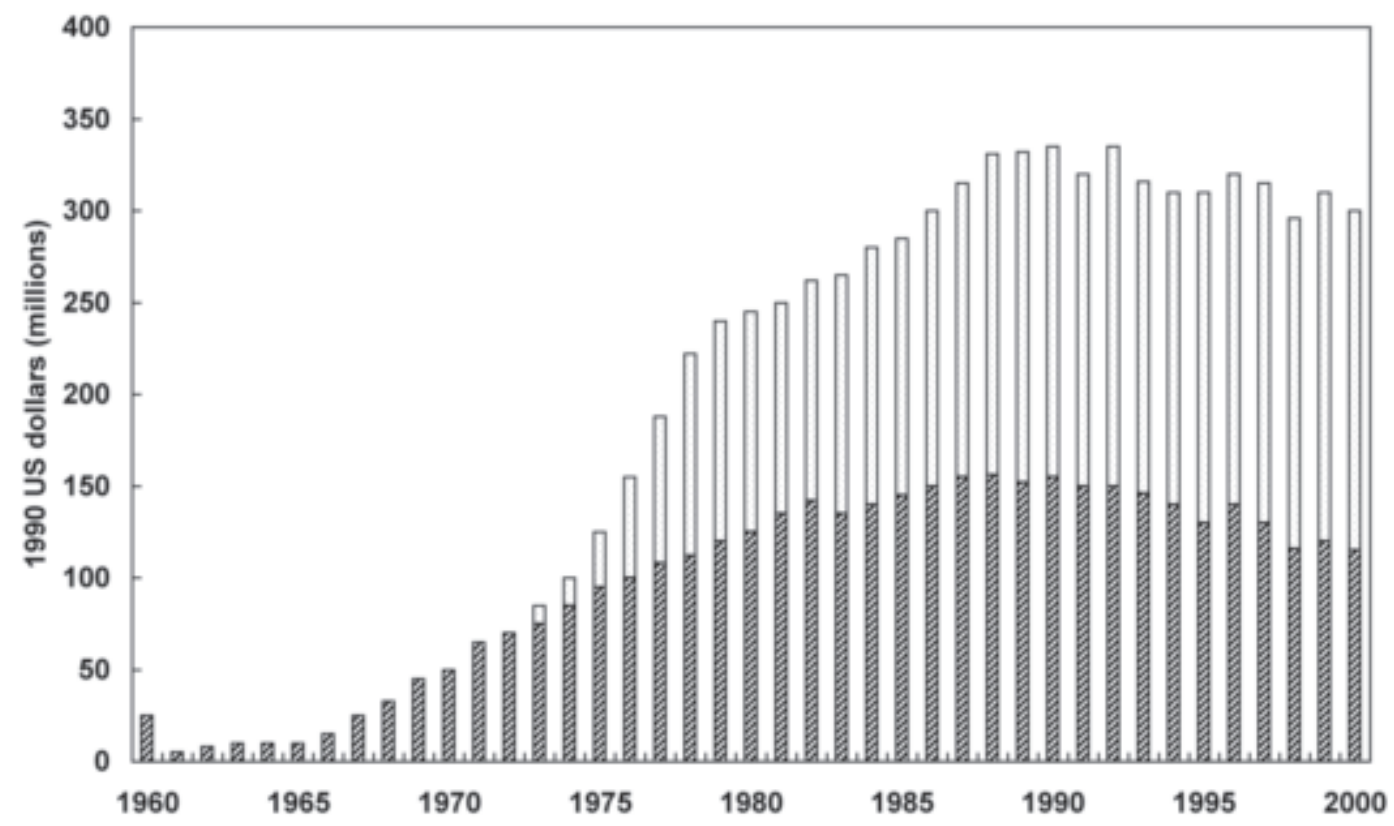


Table 4. Estimated global public and private agricultural R\&D, mid-1990s. Source: Pardey and Beintema (2001).

\begin{tabular}{lrrrrrrrr}
\hline & \multicolumn{3}{c}{ Expenditures $^{2}$} & & \multicolumn{3}{c}{ Shares (\%) } \\
\cline { 2 - 3 } & Public & Private & Total & & Public & Private & Total \\
\hline Developing countries & 11,469 & 672 & 12,141 & & 94.5 & 5.5 & 100.0 \\
Industrialized countries & 10,215 & 10,829 & 21,044 & & 48.5 & 51.5 & 100.0 \\
Total & 21,692 & 11,511 & 33,204 & & 65.3 & 34.7 & 100.0 \\
\hline
\end{tabular}

${ }^{2}$ Units are in 1993 international dollars, using PPP (millions).

Asia, evidence on private investment in agricultural research is very scarce. Case studies from Latin America suggest no clear trend in private agricultural research for the region as a whole. Falconi and Elliot (1995) estimate that spending by private companies accounted for $<15 \%$ of total agricultural research investment in the region. Data cited by Echeverria et al. (1996) suggest that the true figure for Latin America may be lower, given that the share is known to be $<10 \%$ in three of the largest research systems-Argentina, Brazil, and Colombia. Evidence from Africa is sparse but suggests that private investment in agricultural research is very limited. The only African countries with significant amounts of private agricultural research are South Africa, Egypt, and Kenya. In summary, private investment in agricultural research appears to be growing in developing countries, especially in Asia and Latin America, but the total amount of private investment continues to be dwarfed by public expenditures.

Implications for training and capacity building. What have been the implications of these trends in public and private investment for agricultural training and capacity building? Unfortunately, data on training and capacity building are unavailable at the global level. Nonetheless, it is revealing to examine the experience of several organizations that have traditionally played leading roles in supporting capacity building in agriculture, particularly in the developing world.

The World Bank recently reviewed its global expenditures on agricultural research, extension, and higher agricultural education in sub-SaharanAfrica. Based on an analysis of 28 ongoing agricultural projects, Rygnestad et al. (2005) determined that out of a total portfolio of slightly more than $\$ 1$ billion, investments in agricultural training accounted for just over $\$ 70$ million ( $7 \%$ of the total), while investments in agricultural education amounted to a paltry $\$ 5$ million ( $0.5 \%$ of the total). Furthermore, the level of investment fluctuated greatly during the period under review. These figures are consistent with the findings of an earlier global study covering the period 1987-97 conducted by Willett and McGuire (1998). What emerges is a sobering picture of a lack of consistent investment in agricultural capacity building generally and a particularly glaring lack of support for professional training in the agricultural sciences.

The World Bank's record is not unique. The Board for International Food and Agricultural Education (BIFAD) recently reviewed trends in support provided by the U.S. Agency for International Development (USAID) to students from developing countries for long-term training in U.S. universities. In 1990, USAID funded 9,128 students in all disciplines from all developing countries; by 2000 , the number had fallen to 1,212 (BIFAD, 2003). During the same period, new starts for MSc and $\mathrm{PhD}$ training in the agricultural sciences fell from 310 in 1990 to 82 in 2000 . In the wake of " $9 / 11$ " and the tightening of immigration laws, these figures are likely to have fallen further.

Philanthropic foundations, which have long been in the forefront of efforts to build capacity in developing countries, have also scaled back the support they provide for graduate study, particularly in the U.S. The Rockefeller Foundation, long one of the leading sources of scholarships for students from developing countries to pursue MSc and $\mathrm{PhD}$ degrees in the U.S., several years ago took the difficult decision to stop funding students to pursue advanced degrees in plant breeding in the U.S. because of the high cost. The foundation is now pursuing what it believes will be the more cost-effective strategy of sending students to centers of excellence within their own region. The Sasakawa Association has taken a similar approach because the number of students returning from universities in the North had fallen to an extremely low level and because the relevance of the education provided was sometimes questionable.

One reason why many donors are turning away from capacity building in agriculture is that the cost of professional training has increased dramatically. The total cost of supporting a student from a developing country (who normally would not qualify for in-state tuition rates) to pursue an MSc degree followed by a $\mathrm{PhD}$ degree in plant breeding at a typical U.S. land grant university now is in the range of $\$ 150,000$ to $\$ 200,000$. Combined with the fact that fewer and fewer foreign-born graduates have been returning to their home countries to pursue careers, especially careers in agriculture, most donors have decided that the investment is unjustifiable.

Just as support to formal education of plant breeders has fallen, so too has support to training in plant breeding. For example, funding pressures have eroded the capacity of many CGIAR centers to offer general breeder training, and numbers of trainees passing through the centers' plant breeding training programs have declined. Table 7 presents data on the number and types of training courses offered at CIMMYT, one of the oldest and largest centers, and the one with the biggest investment in plant breeding research. At CIMMYT, the relative frequency of plant breeding courses has actually increased, but the absolute number of courses offered has declined due to steep cutbacks in training budgets. Barring a reversal in recent trends, CIMMYT like many other CGIAR centers will be unable to maintain its formerly active role in breeder training and education.

\section{Empirical evidence of declining capacity in plant breeding}

The picture that emerges from these trends is not encouraging for agriculture in general and for the plant breeding industry in particular. In many countries, developing as well as industrialized, public investment in agricultural research has stagnated or even declined. Professional training and scientific capacity building, which have never accounted for more than a small proportion of the total public investment in agriculture, continue to attract negligible portions of a shrinking pie. Squeezed between falling budgets and rising costs, public organizations have responded by scaling back their investments in human capacity building for agriculture. Meanwhile, private investment in agricultural research has increased, but this has predictably focused on developing products with promising commercial applications and easily appropriable benefits. Private companies have shown little inclination to invest in the lengthy and expensive process of educating plant breeders, especially plant breeders who are interested in working on minor crops.

Table 5. Growth of public and private agricultural research in Asia (1995 million dollars). Source: Pray and Fuglie (2002); N/A = not applicable.

\begin{tabular}{|c|c|c|c|c|c|c|c|}
\hline & \multicolumn{3}{|c|}{ Public } & \multicolumn{3}{|c|}{ Private } & \multirow{2}{*}{$\begin{array}{c}\text { Private share } \\
\text { of total } \\
\text { in } 1995 \\
(\%)\end{array}$} \\
\hline & 1985 & 1995 & $\begin{array}{c}\text { Annual } \\
\text { growth } \\
(\%)\end{array}$ & 1985 & 1995 & $\begin{array}{c}\text { Annual } \\
\text { growth } \\
(\%)\end{array}$ & \\
\hline India & 206 & 348 & 5.2 & 26 & 56 & 7.7 & 13.9 \\
\hline China & 403 & 485 & 1.9 & 0 & 16 & --- & 3.2 \\
\hline Indonesia & 62 & 81 & 2.7 & 3 & 6 & 6.9 & 6.9 \\
\hline Malaysia & 44 & 64 & 3.7 & 14 & 17 & 1.9 & 21.0 \\
\hline Philippines & 17 & 38 & 8.0 & 6 & 11 & 6.1 & 22.4 \\
\hline Thailand & 67 & 127 & 6.4 & 11 & 17 & 4.4 & 11.8 \\
\hline Pakistan & $\mathrm{N} / \mathrm{A}$ & $\mathrm{N} / \mathrm{A}$ & $\mathrm{N} / \mathrm{A}$ & 2 & 6 & 11.0 & $\mathrm{~N} / \mathrm{A}$ \\
\hline Total & 800 & 1142 & 3.6 & 62 & 128 & 7.2 & 10.1 \\
\hline
\end{tabular}


Table 6. Global agricultural research spending, mid-1990s (1993 billion dollars per year). Source: Public expenditures from Pardey and Beintema (2001), and private expenditures from Pardey and Beintema (20010 and James (1997).

\begin{tabular}{lcccc}
\hline & \multicolumn{2}{c}{$\begin{array}{c}\text { Private } \\
\text { Public }\end{array}$} & (Pardey and Beintema) & Total \\
\hline Industrialized countries & 10.2 & 10.8 & 11 & $21.0-21.2$ \\
Developing countries & 11.5 & 0.7 & 2 & $12.2-13.5$ \\
Total & 21.7 & 11.5 & 13 & $33.2-34.7$ \\
\hline
\end{tabular}

To what extent is this gloomy picture supported by evidence of a decline in the numbers of practicing plant breeders? Data from two national plant breeding studies show that in the U.S. modest growth in the numbers of breeders working in the private sector has failed to offset steep losses in the number of breeders working in the public sector (Table 8). Not visible in the overall employment numbers is what appears to have been a shift in the focus of many breeders. Table 9 presents data from the same two studies on the main activities being pursued by plant breeders in the U.S. Although comparisons between the 1994 data and the 2001 data are made difficult by the fact that biotechnology was not identified as a distinct activity during the 1994 survey, it is clear that most breeders employed in the public sector engage in upstream research activities (basic plant breeding and germplasm enhancement), whereas most breeders employed by private firms engage in downstream research activities (cultivar development). Combined with the evidence presented in Table 8 that the numbers of breeders employed in the public sector has declined, this evidence underlines the concern that capacity in the upper end of the breeding pipeline has declined (Traxler 1999).

During the period spanned by the two NPBS surveys, there was considerable consolidation in private industry because of buy-outs and mergers, accompanied by the adoption of an agroecological approach to breeding that focused breeding resources around key crop development centers that cater to the needs of regions extending across continents in many cases. If the consolidation taking place in the global plant breeding industry has in fact resulted in efficiencies, it could be argued that previously there were too many breeders. This begs the question of how many breeders are really needed. Some would argue that what is needed is notmore breeders, ratherbetter quality and better trained breeders that are properly supported to meet the needs of the discipline today.

Trends in plant breeding capacity in developing countries are the subject of an ongoing global study being undertaken by FAO (Guimaraes, 2005). Preliminary results of the FAO study suggest that while numbers of breeders continue to rise slowly in many developing countries (though not all), budgets for plant breeding research have remained flat or even declined in many instances. This suggests that breeders in developing nations may be facing greater challenges mobilizing operational funds needed to pursue an increasingly ambitious research agenda.

\section{REBUILDING CAPACITY IN INTERNATIONAL PLANT BREEDING}

Warning signs: An industry under stress. While the evidence is still less than defini- tive, a combination of factors appears to be contributing to a decline in the numbers of new plant breeders coming into the profession. Advances in science, especially the emergence of molecular breeding tools and the associated explosion in information about the genetic basis of plant performance, have greatly expanded the amount and types of knowledge needed to function effectively as a modern plant breeder. Knowledge of traditional field-based selection methods still represents the core competency of the plant breeder, but this must now be complemented by knowledge of emerging laboratorybased tools and techniques, familiarity with an increasingly complex IP environment, and financial management skills.

While the skills and knowledge required for plant breeding have proliferated, the resources being invested in training plant breeders have lagged. Factors contributing to the slowdown are numerous and varied. Declining public investment in agricultural research more generally and in agricultural education and training more specifically reflect the view held by many policy makers that since private firms reap the benefits of plant breeding research, they should contribute more to the cost of educating plant breeders. Yet private firms have failed to fill the widening gap. Many private firms have increased expenditures on training and capacity building in areas where there are prospects for producing profitable commercial technologies, especially biotechnology, but they have not shown a propensity to sponsor graduate education in the more basic skill areas needed by plant breeders, including basic crop science (Knight, 2003).

Most leading seed companies report they now have trouble finding qualified field -oriented breeders. In an attempt to increase future supplies of plant breeders, many seed

Table 7. Numbers of training courses offered at CIMMYT, 1990-2000. Source: CIMMYT training database.

\begin{tabular}{lcccccccccccc}
\hline & 1993 & 1994 & 1995 & 1996 & 1997 & 1998 & 1999 & 2000 & 2001 & 2002 & 2003 & 2004 \\
\hline All courses & 25 & 36 & 34 & 34 & 37 & 40 & 39 & 30 & 28 & 27 & 22 & 9 \\
Plant breeding (no) & 8 & 15 & 12 & 17 & 11 & 14 & 14 & 14 & 10 & 7 & 8 & 4 \\
Plant breeding (\%) & 32 & 41.7 & 35.3 & 50.0 & 29.7 & 35.0 & 35.9 & 46.7 & 35.7 & 25.9 & 36.4 & 44.4 \\
Biotechnology (no) & 1 & 0 & 0 & 1 & 3 & 1 & 4 & 3 & 2 & 0 & 3 & 1 \\
Biotechnology (\%) & 4.0 & 0.0 & 0.0 & 2.9 & 8.1 & 2.5 & 10.3 & 10.0 & 7.1 & 0.0 & 13.6 & 11.1 \\
\hline
\end{tabular}

Table 8. Numbers of plant breeders employed in the U.S., 1994 and 2001 (scientist years). Source: Preliminary National Plant Breeding Study funded by Cooperative State Research, Education and Extension Center-U.S. Department of Agriculture (USDA) and USDA-Economic Research Service. SAES = State Agricultural Experiment Stations; ARS = Agricultural Research Service; columns may not sum due to rounding error.

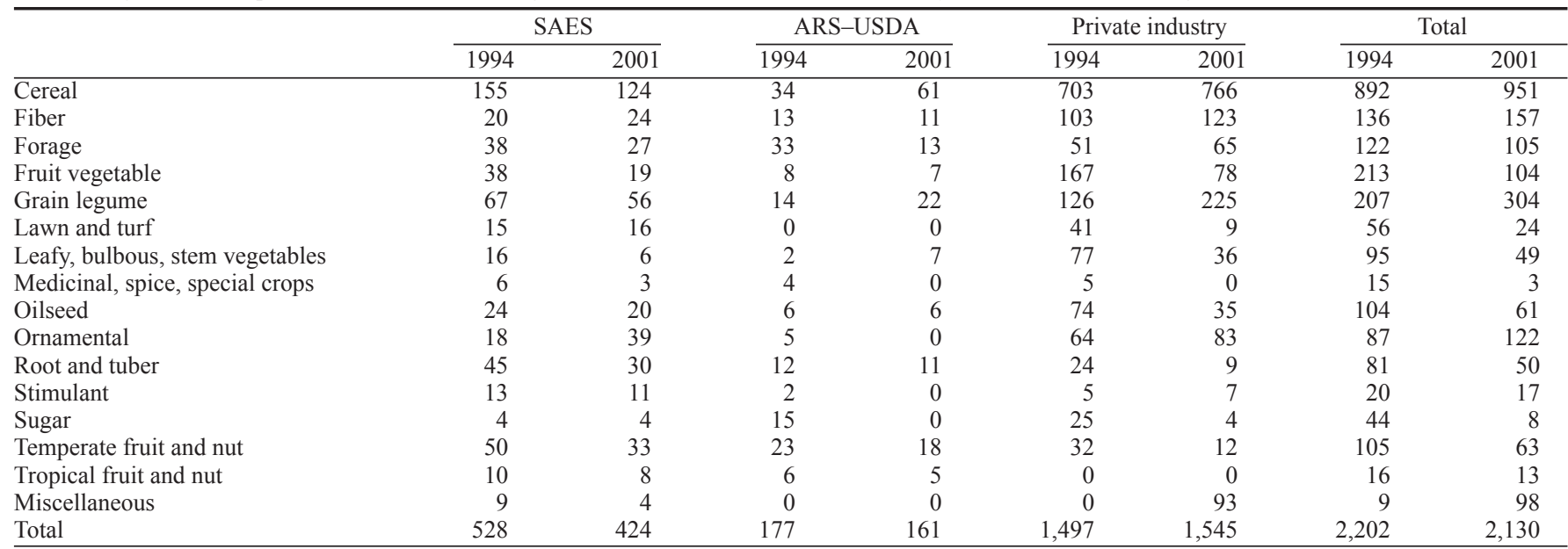


Table 9. Main emphasis of plant breeders employed in the U.S., 1994 and 2001 (scientist years). Source: Preliminary National Plant Breeding Study funded by Cooperative State Research, Education and Extension Center-U.S. Department of Agriculture (USDA) and USDA-Economic Research Service. SAES = State Agricultural Experiment Stations; ARS = Agricultural Research Service; N/A = not applicable.

\begin{tabular}{|c|c|c|c|c|c|c|c|c|}
\hline & \multicolumn{2}{|c|}{ SAES } & \multicolumn{2}{|c|}{ ARS-USDA } & \multicolumn{2}{|c|}{ Private industry } & \multicolumn{2}{|c|}{ Total } \\
\hline & 1994 & 2001 & 1994 & 2001 & 1994 & 2001 & 1994 & 2001 \\
\hline Plant breeding fundamentals & 159 & 85 & 70 & 54 & 143 & 210 & 372 & 403 \\
\hline Germplasm enhancement & 153 & 71 & 85 & 33 & 165 & 96 & 403 & 167 \\
\hline Cultivar development & 217 & 144 & 22 & 22 & 1191 & 673 & 1430 & 817 \\
\hline Subtotal & 529 & 300 & 177 & 109 & 1499 & 979 & 2205 & 1387 \\
\hline Biotechnology & N/A & 124 & N/A & 80 & N/A & 566 & N/A & 769 \\
\hline
\end{tabular}

companies are playing an increasingly active role in educating breeders by offering scholarships, endowing faculty positions, and supporting graduate studies of their own employees. Seed companies are also increasing their in-house training, both informal (e.g., mentoring provided to newly hired breeders) and formal (e.g., web-based and group courses offered on topics such as statistics, marker-assisted selection, genetics, and bioinformatics). The emphasis of in-house training is mainly tactical, however, and broad education in the principles of breeding remains the domain of the universities.

The growing scarcity of experienced and well-rounded plant breeders has had an interesting effect on the deployment of scientific talent. For quite some time, private firms have poached talent from the public sector, enticing successful plant breeders from universities, CGIAR centers, and government research institutes with offers of higher salaries, more attractive working conditions, and the prospect of greater impact. In principle, this is a welcome development, in the sense that it reflects the movement of a scarce resource toward its most productive uses. But a hidden cost is that certain target markets are becoming increasingly neglected. For multinational seed companies, by far the primary focus remains the North American and European markets, plus a small number of developing countries with vibrant commercial farming sectors. Although most multinational seed companies profess to be pursuing a global strategy, not surprisingly they concentrate their efforts on the handful of countries that generate the lion's share of their after-tax profits. This tendency can be seen even within individual firms, as many of the global leaders have had to siphon off scientific talent from their overseas operations to maintain core breeding programs in North America and Europe.

The consequences of this redeployment of a shrinking pool of breeding capacity have been severe, especially for developing countries that lack strong commercial agricultural sectors. Not only are the public breeding programs in these countries losing their best breeders, but private firms based in the North are redeploying staff back to their home countries to maintain a critical mass of scientific manpower addressing commercial crop production there. As a result, research on crops that are of relevance mainly to the developing countries is increasingly neglected, including research on many minor crops that continue to be important food staples and in which productivity gains from plant breeding could have a significant impact hunger and poverty (Naylor et al., 2004).

What is happening today to the human capital base that underpins the plant breeding profession should provide grounds for concern. While some fields of study continue to attract respectable numbers of graduate students, this is not the case with other fields, including some that make up the core curricula of crop science programs in U.S. land grant universities. The migration of increasing numbers of graduate students toward laboratory-based molecular sciences, combined with the reluctance of many to enter traditional field-based areas of specialization now considered outdated and intellectually unexciting, threaten to produce a shortage of plant breeders with a commitment to traditional forms of gene manipulation and phenotypically based field selection skills. The effects are also being felt within the ranks of agricultural faculties, as old-style crop science positions are being lost to new-style molecular science positions that provide more effective platforms for pulling in research grant funding. The result has been a shrinking of traditional long-term plant breeding programs and a noticeable graying of the faculty who remain in those programs.

What we have seen up until now may only be the beginning of a larger trend. Building human capacity in plant breeding is a longterm endeavor. At least 15 and as many as 20 years can elapse between the time a future plant breeder enters a graduate degree program and the time the breeder begins to generate tangible benefits in the form of improved varieties being grown in farmers' fields. The decline observed during the past 15 years in the numbers of breeders being educated and trained may not yet have produced measurable effects, but once the effects become evident, there will a long empty pipeline that will require patience and sustained investment to fill.

Redefining roles and responsibilities. What needs to happen to ensure that the emerging scarcity of plant breeders does not become a dire shortage? Without question, increased investment in capacity building-formal graduate education as well as more informal in-service technical training - will be needed to ensure that an adequate supply of qualified plant breeders is available to sustain international plant breeding efforts. But to say that increased investment will be needed ultimately says very little, because the much more important question concerns who will do what. Simply injecting more resources in an effort to revive the old system will not work, because the system that functioned so well in the past is no longer appropriate. Changes in the distribution of institutional roles and responsibilities will therefore be needed to reverse the current trends.

\section{ROLES FOR PUBLIC ORGANIZATIONS}

Public universities. Public universities will continue to play a critical role in providing the basic scientific education required by plant breeders. However institutional changes will be needed if graduate programs are effectively to address the needs of a global breeding industry that is becoming increasingly concentrated. The current paradigm under which small countries maintain separate graduate programs and large countries maintain multiple graduate programs at the provincial or state level will become increasingly untenable as graduate programs compete to attract fewer and fewer students. With the cost of tertiary education in the agricultural sciences continuing to rise, public universities should be looking to consolidate graduate programs within centers of excellence that can attract enough students to justify their existence. In the case of small countries, this will mean establishing regional centers of excellence where plant breeding is taught at a high level. These centers of excellence are likely to be few in number-perhaps a half-dozen each would suffice for North America and Europe, and three or four each for the major developing regions of sub-Saharan Africa, Latin America, and Asia. These centers of excellence will have to support strong field-based programs focused on germplasm enhancement and cultivar development, along with strong laboratory-based programs focusing on applied genomics.

Assuming a continuation of current downward trends in public investment in agricultural research and education, innovative funding arrangements will be needed to ensure the financial sustainability of plant breeding programs in public universities. One approach that is already being used with some success is for universities to seek funding from the private sector for endowed chairs in the agricultural sciences. Several universities have also been successful in mobilizing resources from the private sector to support student scholarships, faculty study leaves, and faculty sabbaticals. Similar funding could also be sought more aggressively from other sources, including private individuals, philanthropic organizations, and government agencies and donor organizations

Public plant breeding institutes. Public plant breeding institutes will continue to struggle as agricultural research becomes increasingly privatized. Unlike public universities, which can make a reasonable case that human capacity building is a public good requiring public funding, public plant 
breeding institutes will have a difficult time convincing policy makers that their activities cannot be picked up by private firms. To make the argument successfully, public breeding programs will have to move upstream in the research pipeline and concentrate on basic germplasm improvement activities and methodological development work, leaving to the private sector more applied types of research that lead to the development of commercial products, including finished cultivars with good local adaptation. An exception will be minor crops that attract little attention from the private sector.

If they are to move upstream in the research pipeline and still maintain their relevance, public breeding programs will have to strengthen their links with private firms to ensure that their activities maintain relevance for commercial breeding. This will mean not only developing more effective collaboration mechanisms, but also learning to deal more adroitly with the IP dimensions of research. Issues relating to the ownership and control of technologies will assume increased importance, and confidentiality requirements will play a more visible role in influencing flows of technology and information.

CGIAR centers. The CGIAR centers, once a leading source of improved germplasm for the international plant breeding system, have seen their influence decline in the face of stiff competition from the private sector and from stronger NARSs in some countries. While the CGIAR centers are unlikely to again dominate global plant breeding in any single major crop as they did during the boom years of the Green Revolution, if given sufficient backing they could continue to play a key role in the training of plant breeders. Several factors are working in their favor: they are staffed by competent and experienced plant breeders who for the most part are genuinely committed to building capacity in developing countries, they have a regional or agroecological zone focus, they have long histories of working on economically important crops and have over the years built up impressive stocks of knowledge about these crops. In addition they have developed extensive global networks of testing locations and contacts with scientists in national breeding programs and private firms, and they have the facilities needed to host training courses. Many CGIAR centers have had to scale back training programs due to budget cuts, but the trend could be reversed fairly quickly were funding to be increased.

National agricultural research systems (NARSs). Nowhere has the erosion in plant breeding capacity been as dramatic as it has in public NARS. The factors that have contributed to the decline of NARSs breeding programs are well known and include reductions in real terms of public support to agricultural research, reductions in donor support to graduate training in the agricultural sciences, and the brain drain that has occurred as talent has been siphoned off into the private sector. In the absence of a clear commitment on the part of governments in developing countries to fund agricultural research, it is difficult to see this trend re- versing. Yet there are some bright spots in an otherwise somber landscape. Brazil, China, and India have managed to build powerful NARSs with successful plant breeding programs. It is not coincidental that these countries are all very large, with extensive areas planted to economically important crops. It is precisely because these countries are so large that their breeding programs have been able to flourish, since successful improved varieties tend to be planted over extensive areas, generating large benefits and generating handsome returns on research investments. The lesson for smaller countries is clear: plant breeding research can be made economically attractive if it can be housed in regional centers of excellence that are large enough to capitalize on scale economies in research. Regional centers of excellence have long been discussed, but to date little progress has been made in terms of implementation. Recent years however have brought a renewed commitment to regional research coordination bodies, and lately several influential donors including the World Bank have started to mobilize financial support to make them a reality.

Donors. Without changes in the underlying conditions that have made it difficult to keep graduate degree holders from the South productively employed in their own countries, donors are unlikely to revert to their traditional method of supporting capacity building through funding of scholarships for study in the North. This is particularly true as the cost of graduate education in the North has escalated sharply. Some donors have switched to a strategy of funding for graduate education in universities within the South, but at least in the case of plant breeding that strategy offers limited opportunities, because the number of quality plant breeding graduate programs in the South is limited. If donors are to make a significant impact on capacity building in plant breeding, many feel it would have to be through a strong long-term commitment to rebuilding tertiary education in the agricultural sciences (e.g., Eicher, 1990). It is difficult to be optimistic that this will happen. In an age in which more and more donors including the World Bank are adopting results-based performance evaluation systems under which success is often defined in terms of measurable changes in performance indicators over the short- to medium-term, it is difficult to generate enthusiasm for investments in capacity building activities whose benefits are subject to quantification only in the very long run. In addition, the fact that many donors tend to work mainly at the country level complicates the challenge of supporting capacity building efforts at the regional level. Fortunately a number of donors have recently started to revisit the merits of relying exclusively on country-based strategies. For example in Africa several proposals are currently under development to support regional initiatives aimed at building scientific capacity and strengthening research systems, including the Nelson Mandela African Institute of Science and Technology and the Framework for African Agricultural Productivity. Both of these regional initiatives would be funded by consortia of donors including the World Bank, the African Development Bank, and the United Nations.

\section{ROLES FOR PRIVATE FIRMS}

Private firms will invest in educating and training of plant breeders if it makes sound business sense. In considering whether to invest in capacity building activities, what most seed companies look for is a recognizable return on investment and some degree of appropriability. Returns on investment in capacity building are fairly easy to identify. Direct returns are realized through the improved performance of employees. Indirect returns may also be realized in the form of public relations benefits that are reflected in higher share prices for the company or the respect it commands in research, education, seed industry, and civic circles. Corporate boards place considerable value on good corporate citizenship and willingness to collaborate with the public. The appropriability issue is less easily addressed. Well-educated, well-trained plant breeders can be hired by competitors, and proprietary information and knowledge can move with employees when they switch jobs. Confidentiality agreements and noncompete clauses can help minimize the latter, but they cannot eliminate it completely. Fearful of losing some competitive advantage, most firms are reluctant to share information and knowledge that add efficiency to plant breeding operations. However this fear applies mainly to the loss of crop-specific applied information and knowledge held by employees, so practically speaking it has little influence on firms' decisions regarding whether or not to support graduate degree training focusing on broad strategic principles of crop improvement.

Many private firms do in fact support graduate education of plant breeders. For example, Monsanto and Pioneer have played key roles in establishing endowed chairs in plant breeding at the University of Illinois and Iowa State University. Several years ago a consortium of companies provided funds that enabled the continuation of the plant breeding program at the University of Minnesota. Most large seed companies also offer fellowships for graduate training, mainly at U.S. universities. Some, such as Syngenta (through the Syngenta Foundation for Sustainable Agriculture) and Pioneer, offer scholarships and training opportunities for students from the developing world. Furthermore, most firms routinely provide financial support for academic meetings and research conferences. In many cases, they fund travel scholarships to enable the attendance of mid-career breeders from developing countries. These investments in breeder education usually come with no strings attached and are rarely affected by confidentiality issues unless graduate research involves company property.

Private firms also offer many training opportunities. For example, Pioneer makes available 20 to 50 undergraduate professional internships each year, in which prospective future employees spend 3 to 12 months working with Pioneer scientists. Similarly, 
in most years several Postdoctoral Fellows conduct research at Pioneer facilities, under the supervision of Pioneer staff. Not all training activities are directed outward. Most seed companies provide training opportunities that allow staff to upgrade their skills after they have been hired. Typical course offerings include selected topics in molecular breeding, experimental design, information analysis, and human resource management. In-house training is also provided by formal and informal mentoring programs.

Given present staffing trends, further direct investment by the major private sector employers in education of breeders seems inevitable. The current tendency to hire breeders from developing countries to meet industry needs in industrialized countries will eventually become counterproductive. As markets expand in the developing countries, there will be a growing business need to retain the brightest and best of the graduating class in their home countries so that market growth can be sustained. This should be encouraged wherever possible, since the future development of crop improvement in most developing countries will depend on the success of start-up national seed companies and the long-term commitment of seed industry multinationals to these markets.

\section{POTENTIAL OF PUBLIC-PRIVATE PARTNERSHIPS}

Ensuring the future supply of well-trained plant breeders will depend on the ability of many different institutional actors to respond to forces that are changing the way capacity building in the agricultural sciences is paid for and carried out. An important aspect of their response will be their ability to learn to collaborate more effectively. This is not a revolutionary concept. Lee and Dudley (2005), Byerlee and Tripp (2001), Frey (2000), and others have called for the development of a new capacity building paradigm based on stronger publicprivate partnerships. In addition to increasing and extending mechanisms currently used by private firms to channel financial resources into university programs, the new paradigm would broaden breeding education by exposing students to private sector breeding programs through internships, practicums, short courses, and similar hands-on training activities. Private firms would assume an active role in designing and implementing these activities, which implies increased commitments of human and physical resources to complement the financial resources that are already being provided. That said, it is important to note that there are limits to what can be expected of the private sector. The basic education of plant breeders remains a quintessentially public good, so if it is left entirely up to private firms, it will be chronically underfunded and narrowly focused on commercial crops and procedures.

Public-private partnerships can also play a key role in facilitating the emergence of regional and global centers of excellence to provide high-level education in plant breeding. The need for such centers is especially great in developing countries, where the resources available to support tertiary education are stretched well past the breaking point. Governments, national research organizations, and donors should work together to identify a limited number of universities and commit the resources needed to ensure that these can have the critical mass of staff and facilities needed to provide quality education. The private sector should be encouraged to support these centers of excellence by endowing faculty positions, funding student scholarships, offering internships, and offering their own staff to participate in teaching activities. Many current and former staff of seed companies would welcome the chance to shape the next generation of plant breeders, assuming appropriate avenues could be established.

\section{Literature Cited}

Board for International Food and Agricultural Development. 2003. Renewing USAID investment in global long-term training and capacity building in agriculture and rural development. USAID, BIFAD, Wash., D.C.

Byerlee, D., G. Alex, and R.G. Echevarria. 2002 The evolution of public research systems in developing countries: Facing new challenges.In D. Byerlee and R.G. Echeverria (eds.). Agricultural research policy in an era of privatization: Experiences from the developing world. CABI, Wallingford, U.K.

Byerlee, D. and R. Tripp. 2001. Public plant breeding in an era of privatization. ODI natural resource perspectives. 2005. http://www.ciesin.org/IC/ icraf/cgiar.html. ODI, CGIAR, London, U.K.

Cohen, J. 2005. Poorer nations turn to publicly developed GM crops. Nature Biotechnol. p. 23.

Echeverria, R.G., E.J. Trigo, and D. Byerlee. 1996. Institutional change and effective financing of agricultural research in Latin America. World Bank Tech. Paper 330.

Edmeades, G.O., G.S. McMaster, J.W. White, and H. Campos. 2004. Genomics and the physiologist: Bridging the gap between genes and crop response. Field Crops Res. 90:5-18.

Eicher, C.K. 1990. African scientific capacity for agricultural development. Agr. Econ. 4:117-143.

Evenson, B. and D. Gollin (eds.). Impact of the CGIAR on international crop genetic improvement. CABI, Wallingford, U.K.

Falconi, C. and H. Elliot. 1995. Public and private R\&D in Latin American and the Caribbean. In: G.H. Peters and D.D. Hedley (eds.). Agricultural competitiveness: Market forces and policy change. Intl. Assn. Agr. Econ., Dartmouth, U.K.

Frey, K.J. 1996. National plant breeding study. Iowa Agr. Home Econ. Expt. Sta., Ames.

Frey, K.J. 2000. Future priorities for plant breeding. Iowa State Univ. Natl. Plant Breeding Study IV. Spec. Rpt. 102.

Gilmour, A.R., B.R. Cullis, S.J. Welham, and R. Thompson. 1998. ASREML manual. NSW Agr., Orange, NSW, Australia.

Heisey, P.W., C.S. Srinivasan, and C. Thirtle. 2002. Privatization of plant breeding in industrialized countries: Causes, consequences, and public sector response. In: D. Byerlee and R.G. Echeverria (eds.). Agricultural research policy in an era of privatization: Experiences from the developing world. CABI, Wallingford, U.K.

James, C. 1997. Progressing public-private sector partnerships in international agricultural research and development. ISAAA, Ithaca, Brief 4.

Kane, S. and C.K. Eicher. 2004. Foreign aid and the
African farmer. Mich. State Univ. (East Lansing) Dept. Agr. Econ. Staff Paper 2004-13.

Knight, J. 2002. A dying breed. Nature 421:568570

Lamkey, K. 2003. Plant breeding: Research and education agenda. Presented at the Seeds and Breeds Summit, 7 Sept. 2003, Wash., D.C.

Lee, E.A. and J.W. Dudley. 2005. Plant breeding education. In: Proceedings of the Arnel Hallauer Intl. Symp. CIMMYT, Mexico City.

Louwaars, N.P., R. Tripp, D. Eaton, V. Henson Appolonio, R. Hu, M. Mendoza, F. Muhhukku, S. $\mathrm{Pal}$, and J. Wekunda. 2005. Impacts of strengthened intellectual property rights regimes on the plant breeding industry in developing countries. Wageningen Univ., Wageningen (in press).

Morris, M.L. and B. Ekasingh. 2002. Plant breeding research in developing countries: What roles for the public and private sectors? In: D. Byerlee and R.G. Echeverria (eds.). Agricultural research policy in an era of privatization: Experiences from the developing world. CABI, Wallingford, U.K.

Morris, M.L. 2000. Impacts of globalization on national maize seed industries: Lessons from developing countries. In: D. Bigman (ed.). The impact of globalization on the agricultural sector and on public agricultural research in developing countries. CABI, Wallingford, U.K.

Morris, M.L. 1998. Maize seed industries in developing countries. Lynne Rienner Publ., Boulder, Colo.

Naylor, R.L., W.P. Falcon, R.M. Goodman, M.M. Jahn, T. Sengooba, H. Tefera, and R.J. Nelson. 2004. Biotechnology in the developing world: a case for increased investments in orphan crops. Food Policy 29:15-44.

Pardey, P.G., and N.M. Beintema. 2001. Slow Magic: Agricultural R\&D a Century after Mendel. Food Policy Report, International Food Policy Research Institute, Washington, DC.

Pardey, P.G., J. Roseboom, and B. Craig. 1999. Agricultural R\&D investments and impacts. In: J.M. Alston, P.G. Pardey, and V.H. Smith (eds.). Paying for productivity. Johns Hopkins Univ. Press, Baltimore.

Pray, C., K.O. Fuglie, and D. Johnson. 2005. Private agricultural research. Unpubl. Mimeograph.

Pray, C.E. and K.O. Fuglie. 2002. Private investment in agricultural research and international technology transfer in Asia. Intl. Potato Center, Rutgers Univ., and Econ. Res. Serv., Bogor, Indonesia.

Rygnestad, H., R. Rajalahti, and E. Pehu. 2005 (forthcoming). Agricultural education and training in sub-Saharan Africa FY98-04. World Bank, Wash., D.C.

Sinclair, T.R., L.C. Purcell, and C.H. Sneller. 2004. Crop transformation and the challenge to increase yield potential. Trends Plant Sci. 9:70-75.

Tinker, N.A., 2002. Why quantitative geneticists should care about bioinformatics, p. 33-44. In: M.S.Kang (ed.). Quantitative genetics, genomics and plant breeding. CABI, Wallingford, U.K.

Traxler, G. 1999. Balancing basic, germplasm enhancement, and cultivar development research in an evolving U.S. plant germplasm system. AgBioForum 2(1):43-47.

Van Wijk, J. 1997. The impact of intellectual property protection on seed supply. In: R. Tripp (ed.). New seed and old laws: Regulatory reform and the diversification of national seed systems. Overseas Dev. Inst., London.

Willett, A. and C. Maguire. 1998. Support for agricultural education in the World Bank and by other donors. Past and present perspectives. World Bank AKIS Discussion Paper 15 Oct. 